\title{
Cholesterol Degradation Effect Analyzed using Marine Cyanobacterial Species Spirulina subsalsa
}

\author{
Kollimalai Sakthivel* and Kandasamy Kathiresan
}

Centre of Advanced study in Marine Biology, Faculty of Marine Sciences, Annamalai University, India

\begin{abstract}
In this study was designed to understand the mechanisms of cholesterol degradation by cyanobacterial species Spirulina subsalsa. We analyzed the degradation of cholesterol in albino mice using basal feed diet (control) and different concentration $(1 \%, 2 \%$ and $4 \%)$ of cyanobacterial diet. Cholesterol was estimated from the control and cyanobacterial fed to the albino mice. Blood cholesterol level reduced $8.1,24.3,30.6 \%$ in 1,2 and $4 \%$ cyanobacterial diet respectively. Phycobiliproteins are the most abundant soluble protein complexes in cyanobacteria and phycocyanin have $75 \%$ in phycobiliprotein. We concluded, phycocyanin was major role for cholesterol degradation in albino mice.
\end{abstract}

Keywords: Blood serum; Cholesterol; Albino mice; Spirulina

\section{Introduction}

Cyanobacterium Spirulina is free-floating filamentous microalgae with spiral characteristics of its filaments with characteristic of photosynthetic capability [1,2]. Initially it was classified as plant kingdom because of plant pigments as well as photosynthesis ability. Later it was placed in bacteria kingdom based on new understanding on its genetics, physiology and biochemical properties [3]. Naturally it grows in high-salt alkaline water reservoirs in subtropical and tropical areas including America, Asian and Africa [3,4]. It is cultivated and commercialized worldwide due to its nutritional characteristics including high concentration of protein $(\sim 65 \%)$, vitamins and mineral salts $[5,6]$. Over 400 years ago, the Spirulina used as food by Mayas, Toltecs and Kanembu in Mexico during the Aztec civilization [7]. The Intergovernmental Institution for the use of Micro-algae Spirulina Against Malnutrition (IIMSAM) was launched in the middle 70's to promote as high nutritional food to fight against starvation and malnutrition in the world [8].

Cholesterol is a lipid, produced by the liver that is required for various functions, found in some foods. Cholesterol is parent compound of hormone, bile acid and vitamin D [9]. Cholesterol is circulated in the blood by transport protein, which is termed lipoproteins. Lowdensity lipoproteins (LDLs) carry cholesterol from the liver to various body cells, but if there is an excess beyond the cells' requirements, cholesterol can accumulate in the walls of arteries. LDL is therefore sometimes called "bad cholesterol". High-density lipoprotein (HDL), on the other hand, carries cholesterol away from cells to the liver, where it is broken down or treated as a waste product. This lipoprotein is referred to "good cholesterol". A normal or desirable cholesterol level is defined as less than $200 \mathrm{mg}$ of cholesterol per deciliter of blood (mg/ $\mathrm{dL}$ ). Blood cholesterol is considered to be borderline when it is in the range of 200 to $239 \mathrm{mg} / \mathrm{dL}$. Elevated cholesterol level is $240 \mathrm{mg} / \mathrm{dL}$ or above is considered to be hypercholesterolemia. Hypercholesterolemia indicates that, HDL is decreased and LDL is increased [10]. Cholesterol circulates in the blood stream. It is an essential molecule for the human body. Cholesterol is a molecule from which hormones and steroids are made. It is also used maintain nerve cells. Between 75 and $80 \%$ of the cholesterol that circulates in a person's bloodstream is made in that person's liver. The remainder is acquired from outside source. Cholesterol is found in animal sources of food, not found in plants.

Excess of cholesterol is risk factor, cause of death worldwide, each year more than 17 million people or $30 \%$ of all death worldwide and 25 million death are expected in 2020 [11]. The presence of high levels of cholesterol in the blood called Hypercholesterolemia. The Spirulina used in the treatment of many diseases, including Cholesterol degradation [12,13], as well as to reduce body weight in humans [14]. The cholesterol lowering activity of Spirulina was first reported in albino rat [15], followed by in mice [16]. Dietary proteins were shown to influence serum cholesterol concentrations in many studies [17-23].

Reports pointed Spirulina an important breakthrough in trickling the problem of hypercholesterolemia and in animal experiments, it has proved that Spirulina had positive effects in reducing serum total cholesterol and elevating high density lipoprotein (HDL) cholesterol level $[15,16,24-26]$. It contains protein, lipid, chlorophyll, carotenoids, vitamins, minerals, and phycobiliproteins such as C-phycocyanin. Phycocyanin which is anti-oxidizing and anti-inflammatory [27] and gamma linolenic acid (GLA) used for its cholesterol reduction effect [28]. The mechanism of degradation of cholesterol by cyanobacteria has yet to be identified. No researchers have identified any algal protein that exerts cholesterol effect. Therefore, this present study has been undertaken to find the effect of marine cyanobacteria, on body weight as well as blood cholesterol level of albino mice.

\section{Materials Methods}

\section{Feed for a mammalian system}

The diets were prepared by supplementing a basal feed with Spirulina subsalsa dry powered. The dried material of cyanobacteria power was incorporated at 1,2 and $4 \%$ of basal feed. This basal (control) feed was prepared using wheat flour (738 g), Bengal gram (122 g), sucrose $(90 \mathrm{~g})$, vitamin $(10 \mathrm{~g})$ and minerals $(40 \mathrm{~g})$. The diets were used to feed the albino mice (Figure. 1).

*Corresponding author: Kollimalai Sakthivel, Faculty of Marine Sciences, Annamalai University, Tamil Nadu, India, Tel: 914144243223; Fax: 914144243555; E-mail: ksakthi7@yahoo.co.in

Received January 23, 2015; Accepted April 09, 2015; Published April 16, 2015

Citation: Sakthivel K, Kathiresan K (2015) Cholesterol Degradation Effect Analyzed using Marine Cyanobacterial Species Spirulina subsalsa. J Microb Biochem Technol 7: 120-123. doi:10.4172/1948-5948.1000192

Copyright: (c) 2015 Sakthivel K, et al. This is an open-access article distributed under the terms of the Creative Commons Attribution License, which permits unrestricted use, distribution, and reproduction in any medium, provided the original author and source are credited 
A

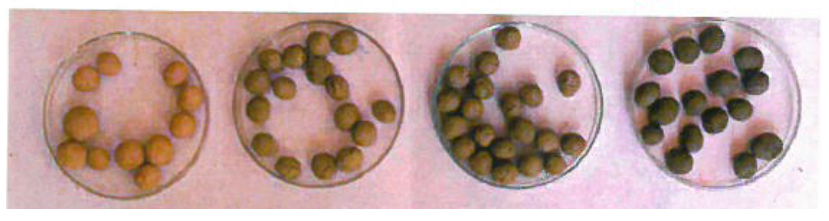

Figure 1: Feed composition of basal feed (A), 1\% (B), 2\% (C), 4\% (D) Spirulina feed.

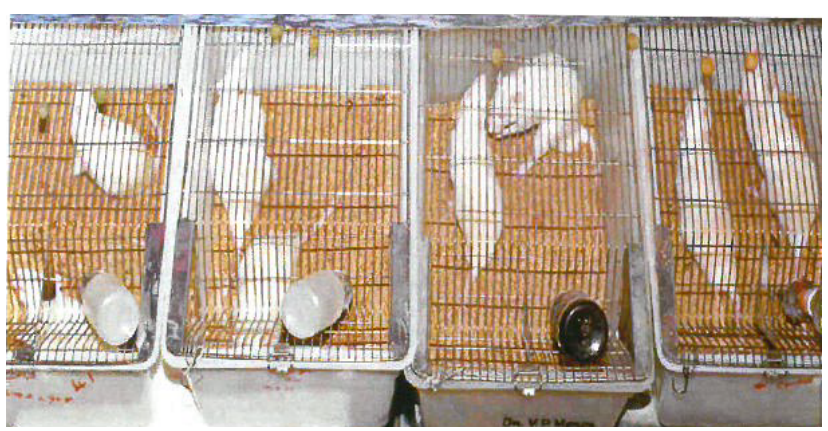

Figure 2: Feeding experiment of caged albino mice.

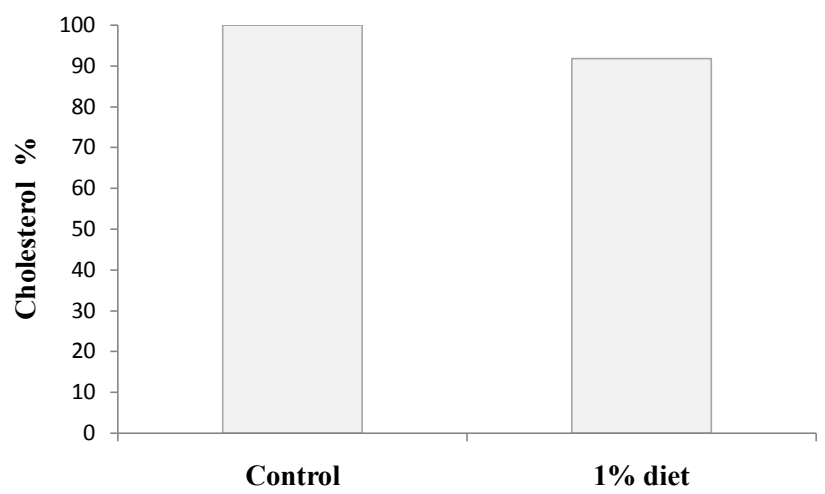

Figure 3: Effect of $1 \%$ cyanobacterial diets on blood cholesterol of albino mice.

\section{Mammalian feeding experiment}

The albino mice used as a testing organisms of mammalian feeding experiment. Male mice of similar size were randomly divided into four groups, each group contain two mice. They were caged individually, and supplied with food and water ad lib. One group of mice was fed on basal diet and used as control. The other three groups were fed on diets of different concentrations $(1,2,4 \%)$ of cyanobacterium. The diets were given twice per day at a rate of $20 \%$ of body weight of mice. The food pellets were kept on the feeding bars of the animal cage (Figure. 2).

\section{Determination of blood cholesterol}

The blood samples were taken only one time from the albino mice at the end of the experiment (after 10 days) and cholesterol were estimated [29]. The blood sample was centrifuged and the serum was collected. In a test tube $0.1 \mathrm{ml}$ of serum was taken, $5 \mathrm{ml}$ of ferric chloride $(0.05 \%$ in acetic acid) and $3 \mathrm{ml}$ of concentrated sulphuric acid were added. After 20 minutes of incubation, absorbance of the reaction mixture was read at $560 \mathrm{~nm}$ against the reagent blank in spectrophotometer. The amount of cholesterol present in the sample was determined by using the standard cholesterol. The results expressed as microgram of cholesterol present in hundred micro litter of blood serum.

\section{Results and Discussion}

\section{Effect of cyanobacterial diets on blood cholesterol of albino mice}

The cyanobacteria Spirulina subsalsa was used as supplemented feed to albino mice for analysis the cholesterol reduced activity (hypercholestrolemic). The results shows, cholesterol level was gradually reduced when increase the percentage of cyanobacteria used as supplementary feed. In control diet without cyanobacteria, albino mice blood cholesterol level was assumed as $100 \%$ level. In the $1 \%$ cyanobacterial diet fed albino mice, the cholesterol level was reduced at $8.1 \%$ (Figure 3). Blood cholesterol level was reduced at $24.3 \%$ in the $2 \%$ cyanobacterial diet fed albino mice (Figure 4 ). The cholesterol level was reduced at $30.6 \%$ in the $4 \%$ cyanobacterial diet fed albino mice (Figure 5). The blood cholesterol are statically significant at 5\% level.

Similar results were reported by other authors. Cholesterol level found be reduced in rabbit by cyanobacterial diet at the rate of $63 \%$ level [30], at the rate of $57 \%$ level [31] and $69.5 \%$ level [23]. The addition of Spirulina in 5, 10 and $15 \%$ in mice diets caused significant inhibition in total cholesterol [32]. Four grams supplementation of

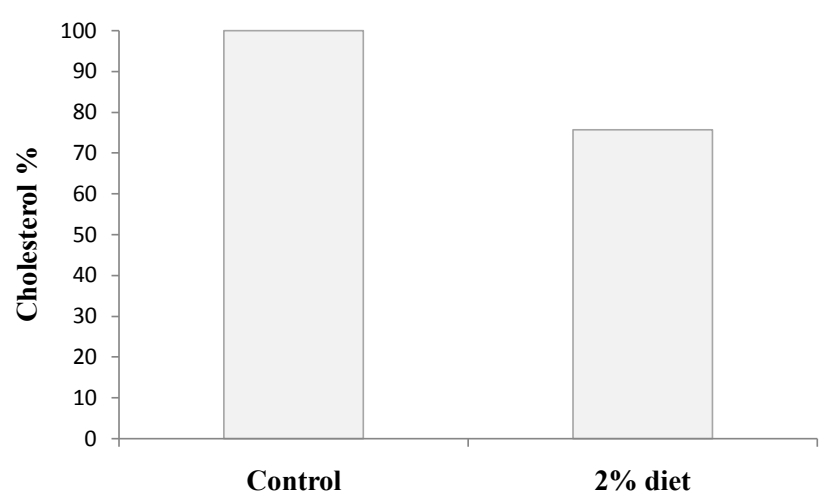

Figure 4: Effect of $2 \%$ cyanobacterial diets on blood cholesterol of albino mice.

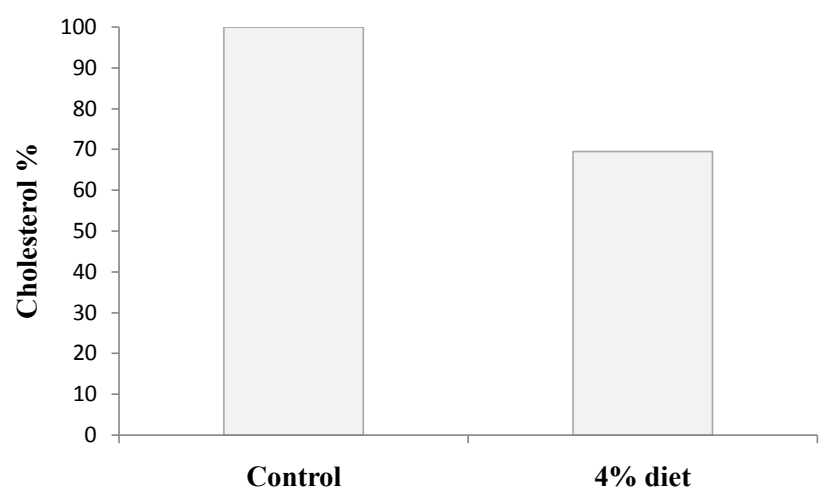

Figure 5: Effect of $4 \%$ cyanobacterial diets on blood cholesterol of albino mice. 
Spirulina recorded the maximum reduction of serum Cholesterol [13]. In the present study $2 \%$ Spirulina fed mice had more reduction of serum cholesterol.

Phycoyanins is the most abundant proteins found in cyanobacterium species of Spirulina. Phycocyanin was characterized as a major phycobiliprotein with a molecular weight of $44 \mathrm{kDa}$ [33]. The relation between the serum cholesterol-lowering activity of dietary protein and the amino acid contents of protein was reported previously [34- 36]. Phycocyanin contain a higher level of cystine than control diet, the differences in amino acid content may relate to the differences in serum cholesterol concentrations. Phycocyanin has antioxidant action $[27,37]$ and confers cholesterol degradation effect against liver damage induced by $\mathrm{CCl}_{4}$ [38]. In Spirulina antioxidant compounds like Phycocyanin, Poly-unsaturated fatty acid may be the reason to decrease of serum cholesterol level. The phycocyanin and proteic pigments extracted from Spirulina, caused hypocholesterolemic activity in rats [21]. Poly-unsaturated fatty acids demonstrated by many authors $[22,39,40]$ compounds respect therapeutic properties such as its ability to decrease blood cholesterol levels $[41,42]$.

This cholesterol degradation may be elicited by some factors(s) such as an enzyme i.e., anticholesterase or unsaponisiable sterols [43]. Thus it is clear that reduce the cholesterol of blood serum in albino mice was due to the diet of cyanobacterial species Spirulina subsalsa. Our conclusion with other authors suggestion is phycocyanin is major role to reduce the blood serum cholesterol of albino mice.

\section{Acknowledgement}

The first author Dr. K. Sakthivel, received Project Scientist position during the manuscript writing from University Grants Commission-Centre with Potential for Excellence in a particular Area (UGC-CPEPA) project.

\section{References}

1. Sapp J (2005) The prokaryote-eukaryote dichotomy: meanings and mythology. Microbiol Mol Biol Rev 69: 292-305.

2. Komarek J, Hauer T (2009) World electronic publication. Univ. of South Bohemia and Inst of Botany AS CR. CyanoDB. cz - On-line database of cyanobacterial genera

3. Vonshak A (1997) Spirulina platensis (Arthrospira): Physiology, Cell-biology and Biotechnology. London, Taylor and Francis.

4. Gershwin ME, Belay A (2008) Spirulina in human nutrition and health. Boca Raton: CRC Press.

5. Henrikson R (1994) Microalga Spirulina - Superalimento del futuro. Barcelona: Ediciones S.A. Urano, ISBN 84-7953-047-2.

6. Belay A, Ota Y, Miyakawa K, Shimamatsu H (1993) Current knowledge on potential health benefits of Spirulina. J Appl Phycol 5: 235-241.

7. Ciferri O, Tiboni O (1985) The biochemistry and industrial potential of Spirulina. Annu Rev Microbiol 39: 503-526.

8. Habib MAB, Parvin M, Huntington TC, Hasan MR (2008) A review on culture, production, and use of Spirulina as food for humans and feeds for domestic animals and fish. FAO Fisheries and Aquaculture Circular No: 1034, Rome.

9. Dilmi-Bouras A (2002) Suivi de Streptococcus thermophilus et de Lactobacillus bulgaricus sur le metabolism du cholesterol, Alger.

10. Kim MH, Kim WY (2005) The change of lipid metabolism and immune function caused by antioxidant material in the hypercholesterolemin elderly women in Korea. Korean J Nutr 38: 67-75.

11. Saile R, Taki H (2007) Cholesterol, lipoproteins et atherosclerose: De la biochimie a la physiopathologie, Les Technologies de Laboratoires 2: 4-11.

12. Nakaya N, Honma Y, GotoY (1988) Cholesterol lowering effect of Spirulina. Nutr Rep Int 37: 1329-1337.

13. Ramamoorthy A, Premakumari S (1996) Effect of supplementation of Spirulina on hypercholesterolemic patients. J Food Sci Technol 33: 124-128.
14. Becker EW, Jakober B, Luft D, Schumuling RM (1986) Clinical and biochemica evaluations of the alga Spirulina with regard of its application in the treatment of obesity. Nutr Rep Int 33: 565-574.

15. Devi MA, Venkataraman LV (1983) Hypocholesterolemic effects of blue green algae Spirulina platensis in albino rats. Nut Rep Int 28: 519-530.

16. Kato T, Tokemoto K, Katayama H, Kuwabara Y (1984) Effects of Spirulina platensis on dietary hypercholesterolemia in rats. J Jpn Soc Nutr Food Sci 37 323-332.

17. Carroll KK, Hamilton RMG (1975) Effects of dietary protein and carbohydrate on plasma cholesterol in relation to atherosclerosis. J Food Sci 40: 18-23.

18. Potter SM (1995) Overview of proposed mechanisms for the hypocholesterolemic effect of soy. J Nutr 125: 606S-611S.

19. Sirtori CR, Even R, Lovati MR (1993) Soybean protein diet and plasma cholesterol: from therapy to molecular mechanisms. Ann N Y Acad Sci 676: 188-201.

20. Zhang X, Beynen AC (1993) Influence of dietary fish proteins on plasma and liver cholesterol concentrations in rats. Br J Nutr 69: 767-777.

21. Nagaoka S, Shimizu K, Kaneko H, Shibayama F, Morikawa K, et al. (2005) A novel protein C-phycocyanin plays a crucial role in the hypocholesterolemic action of Spirulina platensis concentrate in rats. J Nutr 135: 2425-2430.

22. Colla LM, Muccillo-Baisch AL, Costa JAV (2008) Spirulina platensis effects on the levels of total cholesterol, HDL and Triacylglycerols in rabbits fed with a hypercholesterolemic diet. Braz Arch Biol Technol 51: 405-411.

23. Doumandji A, Alili D, Benzaiche A (2012) The effect of dietary supplement Spirulina and Bifidobacterium adolescentis on the cholesterol-lowering in vitro and in vivo. J Life Sci. 6: 740-746.

24. Chen LC, Chen JS, Tung TC (1981) [Effects of spirulina on serum lipoproteins and its hypocholesterolemic activities]. Taiwan Yi Xue Hui Za Zhi 80: 934-942.

25. Iwata K, Inayama T, Kato T (1990) Effects of Spirulina platensis on plasma lipoprotein lipase activity in fructose-induced hyperlipidemic rats. J Nutr Sci Vitaminol (Tokyo) 36: 165-171.

26. Chokkukannan J, Lakshmana M, Aravind SR, Hrishikeshavan HL (1993) Effect of "Spirulina" on serum blood glucose and lipid profile in diabetic rats. Proceedings of the Second Novo Nordisk Diabetes, Jaipur, India.

27. Romay C, Armesto J, Remirez D, González R, Ledon N, et al. (1998) Antioxidant and anti-inflammatory properties of $\mathrm{C}$-phycocyanin from blue-green algae. Inflamm Res 47: 36-41.

28. Samuels R, Mani UV, Iyer UM, Nayak US (2002) Hypocholesterolemic effect of spirulina in patients with hyperlipidemic nephrotic syndrome. J Med Food 5: 91-96.

29. ZLATKIS A, ZAK B, BOYLE AJ (1953) A new method for the direct determination of serum cholesterol. J Lab Clin Med 41: 486-492.

30. Amaral DM, Moreira M, Lobato MA, Abreu SM (1995) Efeito inibidor de substancias antioidantes experimental no Coelho. Vittalle 7: 17-24.

31. Keaney JF Jr, Gaziano JM, Xu A, Frei B, Curran-Celentano J, et al. (1993) Dietary antioxidants preserve endothelium-dependent vessel relaxation in cholesterol-fed rabbits. Proc Natl Acad Sci U S A 90: 11880-11884.

32. Iwata K, Inayama T, Kato T (1987) Effects of Spirulina platensis on fructoseinduced hyperlipidemia in rats. J Jap Soc Nutr Food Sci 40: 463-467.

33. Boussiba S, Richmond AE (1979) Isolation, and characterization of phycocyanins from the blue-green alga Spirulina platensis. Arch. Microbiol 120: $155-159$

34. Jacques H, Deshaies $Y$, Savoie L (1986) Relationship between dietary proteins their in vitro digestion products, and serum cholesterol in rats. Atherosclerosis 61: 89-98.

35. Huff MW, Carroll KK (1980) Effects of dietary proteins and amino acid mixtures on plasma cholesterol levels in rabbits. J Nutr 110: 1676-1685.

36. Sugiyama K, Ohkawa S, Muramatsu K (1986) Relationship between amino acid composition of diet and plasma cholesterol level in growing rats fed a high cholesterol diet. J Nutr Sci Vitaminol (Tokyo) 32: 413-423.

37. Bhat VB, Madyastha KM (2000) C-phycocyanin: a potent peroxyl radical scavenger in vivo and in vitro. Biochem Biophys Res Commun 275: 20-25. 
Citation: Sakthivel K, Kathiresan K (2015) Cholesterol Degradation Effect Analyzed using Marine Cyanobacterial Species Spirulina subsalsa. J Microb Biochem Technol 7: 120-123. doi:10.4172/1948-5948.1000192

38. Vadiraja BB, Gaikwad NW, Madyastha KM (1998) Hepatoprotective effect of C-phycocyanin: protection for carbon tetrachloride and R-(+)-pulegonemediated hepatotoxicty in rats. Biochem Biophys Res Commun 249: 428-431.

39. Olguín EJ, Galicia S, Angulo-Guerrero O, Hernández E (2001) The effect of low light flux and nitrogen deficiency on the chemical composition of Spirulina sp. (Arthrospira) grown on digested pig waste. Bioresour Technol 77: 19-24.

40. Alonso DL, Maroto FG (2000) Plants as 'chemical factories' for the production of polyunsaturated fatty acids. Biotechnol Adv 18: 481-497.
41. Ishikawa T, Fujiyama Y, Igarashi O, Morino M, Tada N, et al. (1989) Effects of gammalinolenic acid on plasma lipoproteins and apolipoproteins. Atherosclerosis 75: 95-104.

42. Kuruahima H, Hayashi K, Shingu T, Kuga Y, Ohtani H, et al. (1995) Opposite effects on cholesterol metabolism and their mechanisms induced by dietary oleic acid and palmitic acid in hamsters. Biochimica et Biophysics Acta 1258: 251-256.

43. Reiner E, Topliff J, Wood JD (1962) Hypocholesterolemic agents derived from sterols of marine algae. Can J Biochem Physiol 40: 1401-1406. 